\title{
USING FALLOUT LEAD-210 MEASUREMENTS TO ESTIMATE SOIL EROSION IN THREE SMALL CATCHMENTS IN SOUTHERN ITALY
}

\author{
PAOLO PORTO ${ }^{1,2, *}$, DES E. WALLING ${ }^{1}$, GIOVANNI CALLEGARI $^{3}$ \\ and FRANCESCO CATONA ${ }^{1,2}$ \\ ${ }^{1}$ Department of Geography, University of Exeter, Exeter, United Kingdom \\ ${ }^{2}$ Dipartimento di Scienze e Tecnologie Agro-Forestali e Ambientali, Università degli Studi \\ Mediterranea di Reggio Calabria, Reggio Calabria, Italy \\ ${ }^{3}$ C.N.R.-Istituto per Sistemi Agricoli e Forestali del Mediterraneo, Sezione Ecologia e Idrologia \\ Forestale, Rende (Cs), Italy \\ ("author for correspondence, e-mail: P.Porto@exeter.ac.uk)
}

(Received 2 September 2005; revised 8 March 2006; accepted 7 June 2006)

\begin{abstract}
Soil erosion and associated off-site environmental impacts have attracted increasing attention in recent decades, and there is a growing need for reliable information on rates of soil loss. The potential for using ${ }^{137} \mathrm{Cs}$ fallout to quantify rates and patterns of soil redistribution over medium-term timescales (ca. 45 years) has been successfully demonstrated in a wide range of environments around the world. The similar behaviour of fallout ${ }^{210} \mathrm{~Pb}$ in soils offers potential for its use as an alternative to ${ }^{137} \mathrm{Cs}$, in areas where ${ }^{137} \mathrm{Cs}$ inventories are low or are complicated by additional fallout from the Chernobyl accident. There have, however, to date been few attempts to validate the use of fallout ${ }^{210} \mathrm{~Pb}$ measurements for assessing erosion rates. This paper reports an attempt to explore the use of fallout ${ }^{210} \mathrm{~Pb}$ to estimate rates of water-induced soil erosion on uncultivated land. It focuses on three small forest/rangeland catchments located in Calabria, southern Italy, for which measurements of sediment output are available. Comparison of the estimates of net soil loss from the catchments derived from ${ }^{210} \mathrm{~Pb}$ measurements with the measured sediment output, confirmed the validity of the ${ }^{210} \mathrm{~Pb}$ approach. The soil redistribution rates estimated using ${ }^{210} \mathrm{~Pb}$ measurements were also consistent with equivalent estimates obtained for the same study catchments using ${ }^{137} \mathrm{Cs}$ measurements.
\end{abstract}

Keywords: soil erosion rates, ${ }^{210} \mathrm{~Pb},{ }^{137} \mathrm{Cs}$, fallout radionuclides, sediment yield, Italy

\section{Introduction}

Soil erosion and the off-site impacts associated with increased fine sediment transport by streams and rivers have attracted increasing attention during recent decades, and sediment is frequently identified as a primary cause of degradation of aquatic habitats. In order to develop an improved understanding of sediment mobilisation and delivery to streams, there is a growing need for reliable information on rates of soil loss in different environments, to provide a basis for identifying the key controls and developing predictive tools. The potential for using nuclear weapon-produced ${ }^{137} \mathrm{Cs}$ fallout to quantify rates and patterns of soil redistribution over medium-term timescales (ca. 45 years) has been successfully demonstrated in a wide range of 
environments around the world (Walling, 1998; Zapata, 2003). There are, however, some important limitations to the ${ }^{137} \mathrm{Cs}$ technique, especially in areas where significant amounts of Chernobyl-derived fallout were received or where the levels of bomb-derived ${ }^{137} \mathrm{Cs}$ are low. The similar behaviour of fallout or excess ${ }^{210} \mathrm{~Pb}$ $\left({ }^{210} \mathrm{~Pb}_{\mathrm{ex}}\right)$ in soils makes it a potential alternative to ${ }^{137} \mathrm{Cs}$ for soil erosion investigations in areas where ${ }^{137} \mathrm{Cs}$ measurements encounter problems and this potential has been recognised and demonstrated (e.g., Walling \& He, 1999; Walling, Collins, \& Sichingabula, 2003). There have, however, to date been few attempts to confirm more widely and validate the use of fallout ${ }^{210} \mathrm{~Pb}$ measurements for assessing erosion rates. This paper reports an attempt to explore the use of fallout ${ }^{210} \mathrm{~Pb}$ to estimate rates of water-induced soil erosion on uncultivated land. It focuses on three small forest/ rangeland catchments, located in Calabria, southern Italy, for which measurements of sediment output are available. Comparison of the estimates of net soil loss from the catchments derived from ${ }^{210} \mathrm{~Pb}_{\mathrm{ex}}$ measurements with the measured sediment output affords a means of validating those estimates.

\section{The Study}

\subsection{THE STUdY CATCHMENTS}

The investigation focussed on three small catchments (W1, W2 and W3) located near Crotone in Calabria, southern Italy (35 m a.s.l., $39^{\circ} 09^{\prime} 02^{\prime \prime} \mathrm{N}, 17^{\circ} 08^{\prime} 10^{\prime \prime} \mathrm{E}$; Figure 1). The catchments ranged in size from 1.38 to 1.65 ha, and were characterized by mean slopes ranging from $24 \%$ to $53 \%$. Further information on the catchments is provided in Table I. The catchments have never been cultivated and originally supported a rangeland vegetation cover (Avolio et al., 1980). Catchment W1 is still covered by rangeland vegetation, but catchments W2 and W3 were

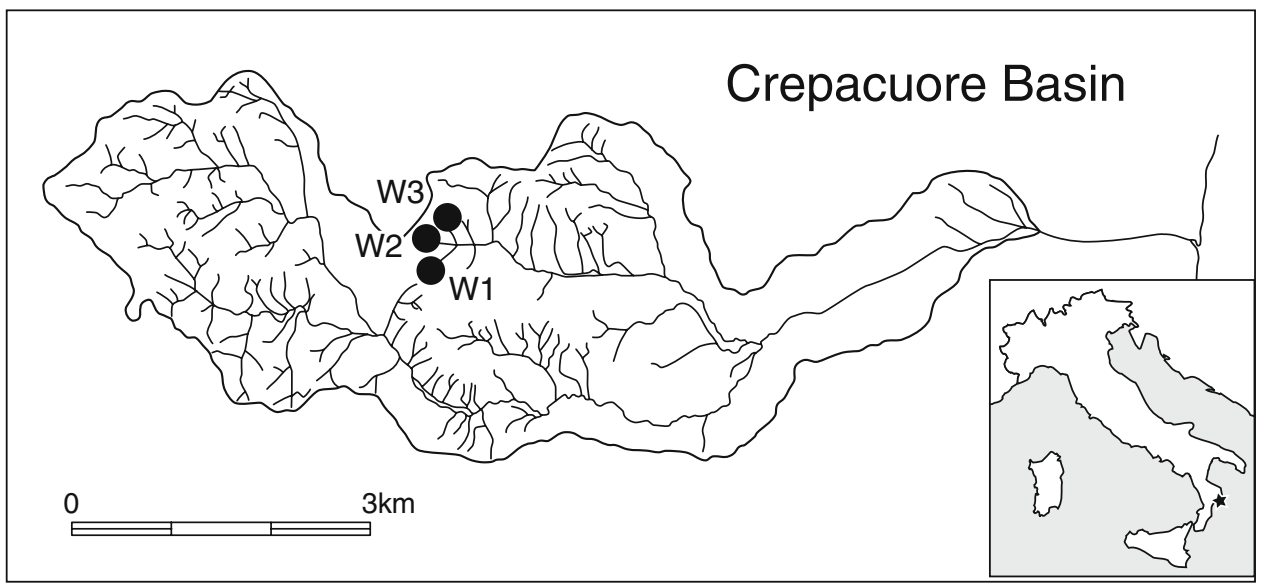

Figure 1. The location of the study catchments. 


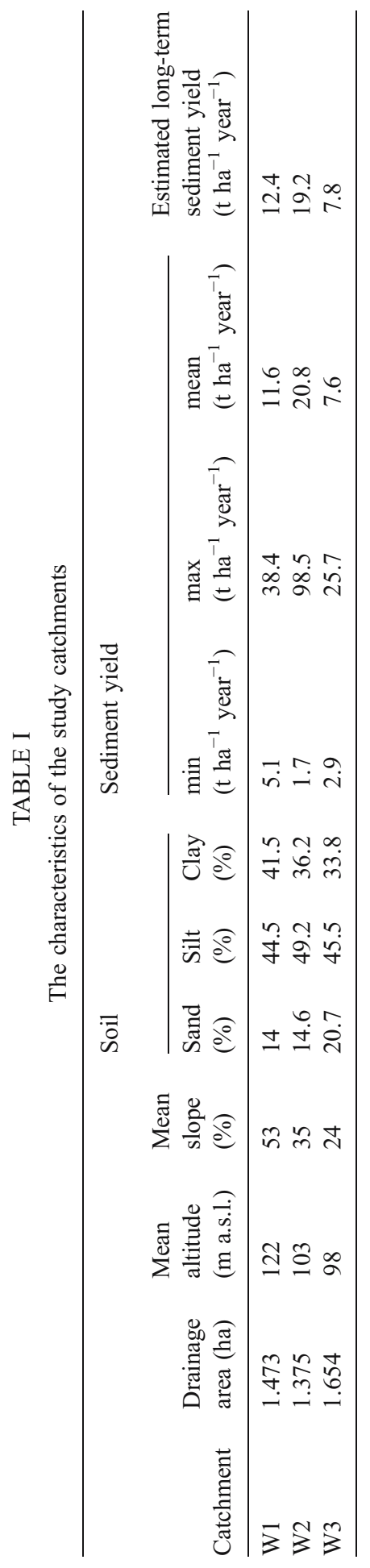


planted with Eucalyptus occidentalis Engl. in 1968. These trees have been cut twice (in 1978 and 1990) in catchment W2 and once (in 1986) in catchment W3. The tree cover in catchment W2 is non-uniform, and about $20 \%$ of its area, located on south facing slopes, is characterized by discontinuous trees and grass cover. In catchment W3 the tree cover is almost continuous and only about $2 \%-3 \%$ of the area supports grass. The climate is typically Mediterranean with a mean annual rainfall of ca. $670 \mathrm{~mm}$, most of which falls between October and March.

In 1978, each catchment was instrumented for measuring rainfall, runoff and sediment yield. Precipitation has been recorded using a tipping bucket rain gauge and runoff is measured at the outlet of each catchment using an $\mathrm{H}$-flume structure, equipped with a mechanical stage recorder. The sediment load passing the gauging structure is measured using a Coshocton wheel sampler installed below the H-flume, which provides values of sediment load for individual events.

\subsection{Sediment YieldS at the CATChment Outlets}

The sediment yield data used in this study cover the period from 1978 to 1994 . Because of malfunctioning of the sediment sampling equipment, values of sediment yield are not available for some events. The sediment loads for these events were estimated using the sediment delivery distributed (SEDD) model (Ferro \& Porto, 2000). Information on the range of the measured values of annual sediment yield values for each catchment is provided in Table I. In order to compare the measured sediment yields from the catchments with the estimates of longer-term net soil loss obtained from the ${ }^{210} \mathrm{~Pb}_{\mathrm{ex}}$ measurements, an estimate of the long-term (ca. 40 year) sediment yield from each catchment was generated by extrapolating the measured values, using the long-term rainfall record for the recording station at Crotone and the predicted temporal variation in canopy cover within the study catchments (see Porto, Walling, \& Ferro, 2001; Porto, Walling, Ferro, \& Di Stefano, 2003). The estimates of mean annual sediment yield for the 43 year period 1956 to 1998 for the three study catchments are also presented in Table I.

\subsection{SOIL SAMPLING AND LABORATORY ANALYSIS}

Soil sampling within the study catchments involved several campaigns undertaken in 1999 and 2001 (see Porto et al., 2003; Porto, Walling, \& Callegari, 2004). Bulk cores were collected at the intersections of an approximately $20 \times 20 \mathrm{~m}$ grid, with additional cores collected to take account of topographic variability. The cores were collected using a steel core tube $(6.9 \mathrm{~cm}$ diameter $)$ driven into the ground by a motorised percussion corer and subsequently extracted using a hand-operated winch. Where tree cover existed in the vicinity of the sampling points, care was taken to ensure that cores were collected from points located between the trees, rather than close to their trunks. Within the study, it has been assumed that the tree cover and associated timber harvesting has not significantly influenced the inventories 
documented for individual sampling points. The samples used to establish the reference inventory were collected from an area of undisturbed rangeland with minimal slope within catchment W1. In this case a scraper plate (cf. Campbell, Loughran, \& Elliott, 1988) with a surface area of $652 \mathrm{~cm}^{2}$ was used to collect samples at depth increments ranging from 1 to $4 \mathrm{~cm}$ to a depth of $50 \mathrm{~cm}$. Six additional $8.6 \mathrm{~cm}$ diameter soil cores were collected from the reference site and sectioned into $2 \mathrm{~cm}$ depth increments, in order to assess the local spatial variability of the ${ }^{210} \mathrm{~Pb}_{\mathrm{ex}}$ inventories and the associated depth distributions. Because of the greater surface area associated with the scraper plate $\left(652 \mathrm{~cm}^{2}\right)$, the inventory obtained from these samples was used as the reference inventory. All samples were initially oven dried at $45^{\circ} \mathrm{C}$, disaggregated and passed through a $2-\mathrm{mm}$ sieve. A representative fraction of each sample was then placed into a plastic pot or Marinelli beaker for determination of its ${ }^{210} \mathrm{~Pb}_{\mathrm{ex}}$ activity. The samples were sealed for 20 days prior to assay in order to achieve equilibrium between ${ }^{226} \mathrm{Ra}$ and its daughter ${ }^{222} \mathrm{Rn}$.

${ }^{210} \mathrm{~Pb}_{\text {ex }}$ activities in the samples were assayed by gamma-ray spectrometry, using a low-background, low energy, high-resolution coaxial HPGe detector coupled to an amplifier and PC-based data collection system and measurements of both the total ${ }^{210} \mathrm{~Pb}$ and the ${ }^{226} \mathrm{Ra}\left(\right.$ via $\left.^{214} \mathrm{~Pb}\right)$ activity. Count times were typically ca. 30,000 s, providing results with an analytical precision of ca. $10 \%$ at the $95 \%$ level of confidence.

\subsection{The FAllout ${ }^{210} \mathrm{~Pb}$ InVEntory AND DePth Distribution AT THE REFERENCE SITE}

Figure 2 provides representative information on the depth distribution of ${ }^{210} \mathrm{~Pb}_{\mathrm{ex}}$ at the reference site in catchment $\mathrm{W} 1$. The ${ }^{210} \mathrm{~Pb}_{\mathrm{ex}}$ is found to a depth of about $40 \mathrm{~cm}$ in the soil profile, and shows evidence of an exponential decrease with depth, with the greatest concentration at the surface $\left(47.7 \mathrm{~Bq} \mathrm{~kg}^{-1}\right)$. Based on this core, the reference inventory is estimated to be $5,266 \mathrm{~Bq} \mathrm{~m}^{-2}$ and this value is in close agreement with the mean value obtained from the six additional $8.6 \mathrm{~cm}$ diameter soil cores $\left(5,440 \mathrm{~Bq} \mathrm{~m}^{-2}\right)$ Assuming a constant deposition flux, the annual atmospheric ${ }^{210} \mathrm{~Pb}$ deposition flux rate in the study area, averaged over the last century (five half-lives), is estimated to be ca. $161 \mathrm{~Bq} \mathrm{~m}^{-2}$ year $^{-1}$.

\section{5. ${ }^{210} \mathrm{~Pb}_{\text {ex }}$ InVEntories Within the StUdy CATChMENTS}

The range of values of ${ }^{210} \mathrm{~Pb}_{\mathrm{ex}}$ inventory obtained for the bulk cores collected from the three catchments are listed in Table II. Inventories are less than the local reference inventory $\left(5,266 \mathrm{~Bq} \mathrm{~m}^{-2}\right)$ over a large part of each of the catchments, suggesting that their surfaces are characterized by net soil loss and that there is little or no storage of eroded sediment within the catchments. In order to explore the relationship between ${ }^{210} \mathrm{~Pb}_{\mathrm{ex}}$ inventories and topography, digital elevation models $(3 \times 3 \mathrm{~m}$ grid size $)$ were created for the three catchments from the survey data provided by Avolio et al. (1980), using a kriging interpolation procedure. An interpolated map of ${ }^{210} \mathrm{~Pb}_{\mathrm{ex}}$ 


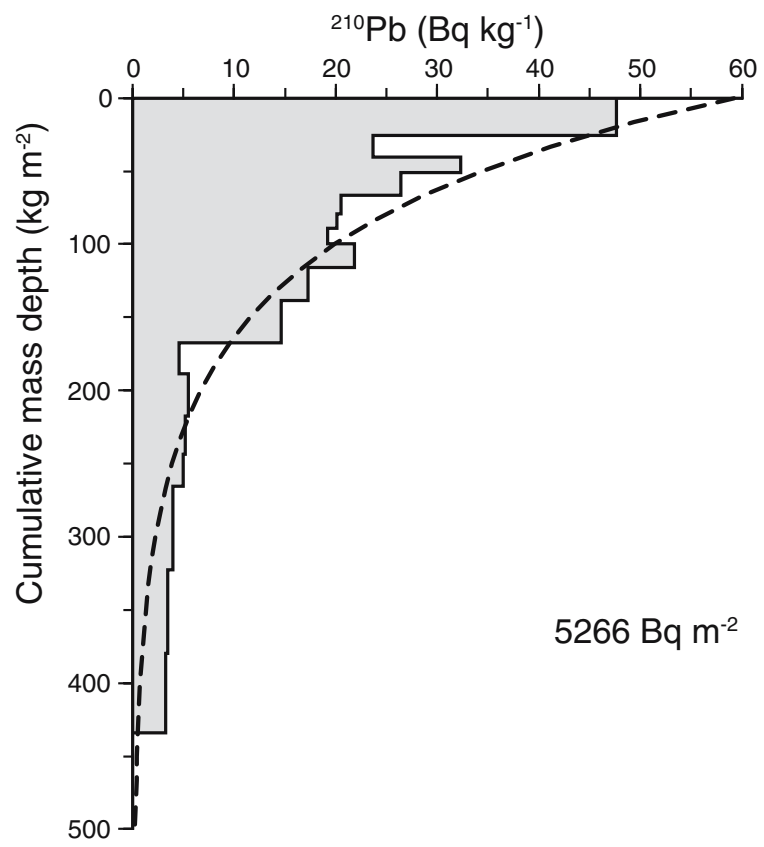

Figure 2. The ${ }^{210} \mathrm{~Pb}_{\mathrm{ex}}$ depth distributions documented for the reference site and the result of fitting the diffusion and migration model [Equation (1)] to this profile.

inventories, produced using the same kriging procedure, has been overlaid onto each DEM and an example is provided for catchment W1 in Figure 3a. The interpolated spatial patterns of ${ }^{210} \mathrm{~Pb}_{\mathrm{ex}}$ inventory for the study catchments show only limited dependence on topographic variability and appear to be more sensitive to variations in vegetation cover density. For example, the areas of discontinuous forest cover within the portions of catchment W2 facing south are marked by lower ${ }^{210} \mathrm{~Pb}_{\mathrm{ex}}$ inventories, which are in turn indicative of higher rates of soil loss.

\subsection{USing ${ }^{210} \mathrm{~Pb}_{\mathrm{EX}}$ MEASUREMENTS to Estimate ERosion Rates}

Estimation of rates of soil loss from ${ }^{210} \mathrm{~Pb}_{\mathrm{ex}}$ measurements is commonly based on a comparison of the inventory measured at a specific point with the reference

TABLE II

Excess ${ }^{210} \mathrm{~Pb}$ inventories and estimates of soil erosion rates within the study catchments

\begin{tabular}{|c|c|c|c|c|c|c|}
\hline Catchment & $\begin{array}{l}\text { Min } \\
\left(\mathrm{Bq} \mathrm{m}^{-2}\right)\end{array}$ & $\begin{array}{l}\operatorname{Max} \\
\left(\mathrm{Bq} \mathrm{m}^{-2}\right)\end{array}$ & $\begin{array}{l}\text { Mean } \\
\left(\mathrm{Bq} \mathrm{m}^{-2}\right)\end{array}$ & $\begin{array}{l}\text { Total } \\
\text { soil erosion } \\
\left(\mathrm{t} \mathrm{ha}^{-1} \text { year }^{-1}\right)\end{array}$ & $\begin{array}{l}\text { Total } \\
\text { deposition } \\
\left(\mathrm{t} \mathrm{ha}^{-1} \text { year }^{-1}\right)\end{array}$ & $\begin{array}{l}\text { Net soil } \\
\text { erosion } \\
\left(\mathrm{t} \mathrm{ha}^{-1} \text { year }^{-1}\right)\end{array}$ \\
\hline W1 & 50.5 & 22,373 & 6,499 & 13.9 & 7.66 & 6.2 \\
\hline W2 & 11.6 & 11,117 & 2,868 & 15.7 & 3.63 & 12.1 \\
\hline W3 & 49.6 & 16,322 & 7,438 & 20.6 & 9.5 & 11.1 \\
\hline
\end{tabular}




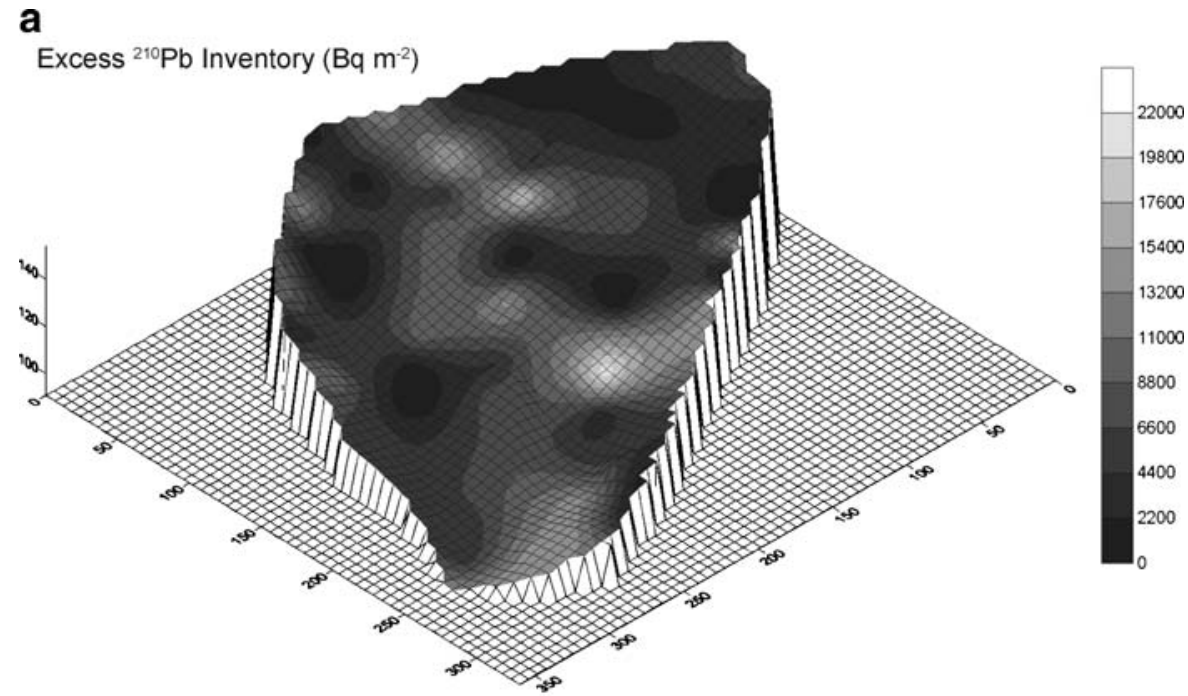

b

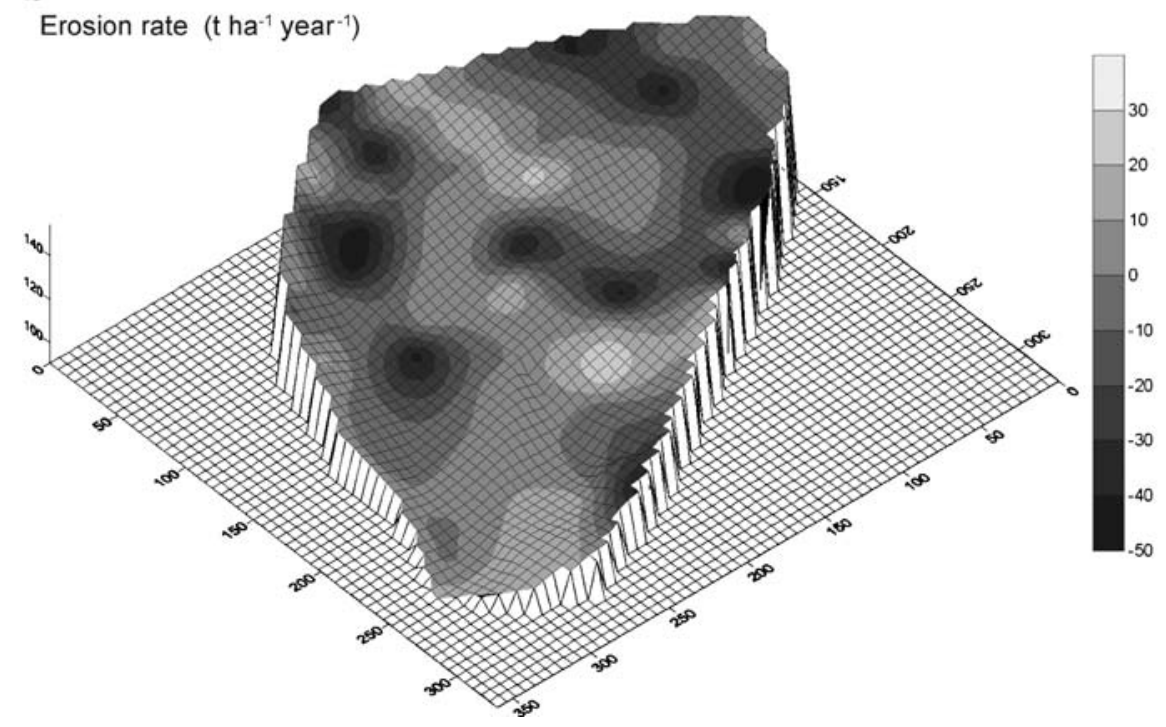

Figure 3. The spatial distribution of ${ }^{210} \mathrm{~Pb}_{\mathrm{ex}}$ inventories $\left(\mathrm{Bq} \mathrm{m}^{-2}\right)$ a and the erosion rates estimated from these data $\left(\mathrm{t} \mathrm{ha}^{-1}\right.$ year $\left.^{-1}\right) \mathbf{b}$ in catchment $\mathrm{W} 1$.

inventory and the degree of reduction of that inventory. The relationship used in this study to convert the magnitude of the reduction in the ${ }^{210} \mathrm{~Pb}_{\mathrm{ex}}$ inventory to an estimate of the rate of soil loss employs a theoretical diffusion and migration model to represent the vertical distribution of ${ }^{210} \mathrm{~Pb}_{\mathrm{ex}}$ within the soil.

According to He and Walling (1997), by treating the soil as a semi-infinite homogeneous porous medium, characterized by a constant effective diffusion coefficient and a constant migration rate, and assuming that fallout inputs are 
initially uniformly distributed at the soil surface, the vertical distribution of ${ }^{210} \mathrm{~Pb}_{\mathrm{ex}}$ activity from the surface downwards can be represented by the equation:

$$
C(x)=C(0) e^{-\beta x}
$$

where:

$x$ mass depth from soil surface $\left(\mathrm{kg} \mathrm{m}^{-2}\right)$;

$C(x)$ concentration of ${ }^{210} \mathrm{~Pb}_{\mathrm{ex}}$ at depth $x\left(\mathrm{~Bq} \mathrm{~kg}^{-1}\right)$;

$C(0)$ concentration of ${ }^{210} \mathrm{~Pb}_{\mathrm{ex}}$ in the surface soil $\left(\mathrm{Bq} \mathrm{kg}^{-1}\right)$;

$\beta$ constant $\left(\mathrm{kg} \mathrm{m}^{-2}\right)$ defined as:

$$
\beta=\frac{1}{2}\left(\sqrt{\frac{V^{2}}{D^{2}}+\frac{4 \lambda}{D}-\frac{V}{D}}\right)
$$

where:

$D$ the effective diffusion coefficient $\left(\mathrm{kg}^{2} \mathrm{~m}^{-4}\right.$ year $\left.{ }^{-1}\right)$;

$V$ the downward migration rate $\left(\mathrm{kg} \mathrm{m}^{-2}\right.$ year $\left.^{-1}\right)$;

$\lambda$ the radionuclide decay constant (year ${ }^{-1}$ );

Equation (1) was used to simulate the fallout profile shown in Figure 2. The estimated value for $\beta$ of $0.91 \mathrm{~kg} \mathrm{~m}^{-2}$ was obtained by varying the values of $V$ and $D$ to minimise the sum of the squares of the deviations between the modelled and observed depth distribution. The fitted result is depicted in Figure 2.

Integration of $C(x)$ over mass depth $x$ gives the total ${ }^{210} \mathrm{~Pb}_{\mathrm{ex}}$ inventory $A_{u}$ $\left(\mathrm{Bq} \mathrm{m}^{-2}\right)$ for an undisturbed site at time $t$ :

$$
A_{u}(t)=\int_{0}^{\infty} C(x, t) \mathrm{d} x
$$

At a location experiencing water-induced erosion, the rate of soil loss $R_{e}$ $\left(\mathrm{kg} \mathrm{m}^{-2}\right.$ year $\left.{ }^{-1}\right)$ can be estimated from the reduction in the ${ }^{210} \mathrm{~Pb}_{\mathrm{ex}}$ inventory $\left(A_{u, l s}(t)\right.$ compared with the local reference value, in combination with information on the ${ }^{210} \mathrm{~Pb}$ content of the eroded soil $C_{e}\left(t^{\prime}\right)$ :

$$
A_{u, l s}(t)=\int_{0}^{t} R_{e} C_{e}\left(t^{\prime}\right) e^{-\lambda\left(t-t^{\prime}\right)} \mathrm{d} t^{\prime}
$$

Alternatively, at a location experiencing water-induced deposition, the rate of sedimentation $R_{d}\left(\mathrm{~kg} \mathrm{~m}^{-2}\right.$ year $\left.^{-1}\right)$ can be estimated from the increase in the ${ }^{210} \mathrm{~Pb}_{\text {ex }}$ inventory $\left(A_{u, e x}\left[\mathrm{~Bq} \mathrm{~m}{ }^{-2}\right]\right)$ compared with the local reference value, coupled with information on the ${ }^{210} \mathrm{~Pb}$ content of deposited sediment $C_{d}\left(t^{\prime}\right)$ :

$$
R_{d}=\frac{A_{u, e x}}{\int_{0}^{t} C_{d}\left(t^{\prime}\right) e^{-\lambda\left(t-t^{\prime}\right)} \mathrm{d} t^{\prime}}
$$


Assuming that the ${ }^{210} \mathrm{~Pb}_{\mathrm{ex}}$ concentration $C_{d}\left(t^{\prime}\right)$ of deposited sediment can be represented by the weighted mean of the ${ }^{210} \mathrm{~Pb}_{\mathrm{ex}}$ concentration of the sediment mobilized from the upslope contributing area, $C_{d}\left(t^{\prime}\right)$ can be calculated

$$
C_{d}\left(t^{\prime}\right)=\frac{1}{\int_{S} R_{d} S} \int_{S} C_{e}\left(t^{\prime}\right) R_{d} S
$$

where $C_{e}\left(t^{\prime}\right)\left(\mathrm{Bq} \mathrm{kg}^{-1}\right)$ is the ${ }^{210} \mathrm{~Pb}_{\mathrm{ex}}$ concentration of mobilised sediment and $S$ is the upslope contributing area $\left(\mathrm{m}^{2}\right)$.

\section{Results}

3.1. Comparing the Estimates of Net SoIl Loss Derived From the ${ }^{210} \mathrm{~Pb}$ MEASUREMENTS WITH THE MEASURED SEDIMENT YielDS AT THE CATCHMENT OUTLETS

The ${ }^{210} \mathrm{~Pb}_{\mathrm{ex}}$ inventories measured for individual soil cores, were used with Equations (4) and (5) to provide estimates of soil redistribution rates $\left(\mathrm{t} \mathrm{ha}^{-1}\right.$ year $\left.^{-1}\right)$. These point values were then interpolated by using a kriging interpolation procedure to derive a map of soil redistribution rates for each catchment. As an example, the map produced for catchment $\mathrm{W} 1$ is presented in Figure 3b. The resulting estimates of soil redistribution rate were then spatially averaged to produce a sediment budget for each catchment, which comprised information on the total erosion, total deposition and the net soil loss. The estimates of net soil loss ( $\mathrm{t} \mathrm{ha}{ }^{-1}$ year $^{-1}$ ) obtained for each catchment can be compared with the values of sediment yield based on the measurements at the catchment outlet, in order to provide a test of the validity of these estimates (see Table III). Taking account of the uncertainties associated with both the measured sediment yields and the procedure used to extrapolate those values to obtain an estimate of the longer-

TABLE III

Comparison of the estimates of net erosion rate obtained for the study catchments using ${ }^{137} \mathrm{Cs}$ and ${ }^{210} \mathrm{~Pb}_{\mathrm{ex}}$ measurements with the estimates of long-term sediment yield based on measurements at the catchment outlets

\begin{tabular}{llcc}
\hline & \multicolumn{1}{l}{ Net soil erosion $\left(\mathrm{t} \mathrm{ha}^{-1}\right.$ year $\left.^{-1}\right)$} & \\
\hline Catchment & $\mathrm{W} 1$ & $\mathrm{~W} 2$ & $\mathrm{~W} 3$ \\
${ }^{137} \mathrm{Cs}$ & 8.6 & 14.0 & 11.3 \\
${ }^{210} \mathrm{~Pb}$ & 6.2 & 12.1 & 11.1 \\
Measured sediment yield & 12.4 & 19.2 & 7.8 \\
\hline
\end{tabular}


term sediment yield, as well as those associated with the estimates of net erosion rate obtained from the ${ }^{210} \mathrm{~Pb}_{\mathrm{ex}}$ measurements, the estimates of net soil loss reported in Table III, are in reasonable agreement with the equivalent measured values of sediment output. These results therefore provide a first-order demonstration that ${ }^{210} \mathrm{~Pb}_{\text {ex }}$ measurements provide a viable means of estimating net erosion rates in the study catchments. Further work is, however, clearly required to explore the contrasts in both the absolute and relative values of net erosion rate obtained using the two approaches.

\subsection{COMPARISON With Estimates of Net SoIL Loss ObTAINED Using ${ }^{137}$ CS MEASUREMENTS}

In previous papers, Porto et al. $(2001,2003,2004)$ explored the use of the ${ }^{137} \mathrm{Cs}$ technique to provide estimates of soil erosion rates within the same catchments. The results obtained from the ${ }^{210} \mathrm{~Pb}_{\mathrm{ex}}$ measurements are in close agreement with the values obtained from the ${ }^{137} \mathrm{Cs}$ measurements, in both absolute and relative terms (see Table III) and this comparison provides a further validation of the use of ${ }^{210} \mathrm{~Pb}_{\text {ex }}$ measurements to estimate erosion rates in the study catchments. There are, however, some minor contrasts between the results obtained using the two radionuclides. Whereas, the ${ }^{137} \mathrm{Cs}$ results show evidence of significant deposition only for catchment $\mathrm{W} 1$, the soil redistribution rates derived from the ${ }^{210} \mathrm{~Pb}_{\mathrm{ex}}$ measurements, reported in Table II, show some deposition occurring in all the three catchments, although this is very limited within catchment W2. These apparently contrasting results may reflect the different behaviour of the two radionuclides in terms of their fallout and their distribution in the soil profile and the greater sensitivity of the ${ }^{210} \mathrm{~Pb}_{\mathrm{ex}}$ approach to recent erosion events, due to the continuous fallout input of ${ }^{210} \mathrm{~Pb}_{\mathrm{ex}}$ and its shorter half-life.

\section{Conclusions}

The results obtained from this investigation undertaken in three small catchments in southern Italy confirm the potential for using fallout ${ }^{210} \mathrm{~Pb}$ to document soil erosion rates on uncultivated soils in this environment. The availability of information on the sediment output from the study catchments permits a direct comparison with an equivalent spatially averaged estimate of the erosion rate for the same areas, derived from ${ }^{210} \mathrm{~Pb}_{\mathrm{ex}}$ measurements. The results of the comparison show that the erosion rate estimates obtained from the ${ }^{210} \mathrm{~Pb}_{\mathrm{ex}}$ measurements are reasonably consistent with the measured sediment yields at the catchment outlets, when the various uncertainties associated with both data sets are recognised. In addition, the ${ }^{210} \mathrm{~Pb}_{\mathrm{ex}}$ results are in close agreement with those obtained from the same catchments using ${ }^{137} \mathrm{Cs}$ measurements. Further studies are clearly required to explore the potential for using fallout ${ }^{210} \mathrm{~Pb}$ to estimate erosion rates on cultivated soils in the study area and in other 
environments, but the results reported in this paper provide further confirmation of the validity of the approach.

\section{Acknowledgments}

The study reported in this paper was supported by an EC Marie Curie Fellowship (MCF1-2000-00096) awarded to the first author, by grants from MURST, and by IAEA Technical Contract 12094. Thanks are also extended to Mr. G. Guarnaccia and Mr. D. Porcino for assistance with fieldwork and to Sue Rouillard for producing the diagrams.

\section{References}

Avolio, S., Ciancio, O., Grinovero, C., Iovino, F., Mirabella, A., Raglione, M., et al. (1980). Effetti del tipo di bosco sull'entità dell'erosione in unità idrologiche della Calabria-Modelli erosivi. Annali Istituto Sperimentale Selvicoltura, 11, 45-131 (in Italian).

Campbell, B. L., Loughran, R. J., \& Elliott, G. L. (1988). A method for determining sediment budget using caesium-137. In M. P. Bordas \& D. E. Walling (Eds.), Sediment Budgets (Proceedings of the Porto Alegre Symposium), International Association of Hydrological Sciences Publication 174 (pp. 171-179). Wallingford, UK: IAHS.

Ferro, V., \& Porto, P. (2000). Sediment delivery distributed (SEDD) model: Theoretical analysis and experimental validation. Journal of Hydrologic Engineering, 5, 411-422.

He, Q., \& Walling, D. E. (1997). The distribution of fallout ${ }^{137} \mathrm{Cs}$ and ${ }^{210} \mathrm{~Pb}$ in undisturbed and cultivated soils. Applied Radiation Isotopes, 48, 677-690.

Porto, P., Walling, D. E., \& Callegari, G. (2004). Validating the use of caesium-137 measurements to estimate erosion rates in three small catchments in southern Italy. In V. Golosov, V. Belyaev, \& D. E. Walling (Eds.), Sediment Transfer through the Fluvial System (Proceedings of a symposium held in Moscow, August 2004) International Association of Hydrological Sciences Publication 288 (pp. 75-83). Wallingford, UK: IAHS.

Porto, P., Walling, D. E., \& Ferro, V. (2001). Validating the use of caesium-137 measurements to estimate soil erosion rates in a small drainage basin in Calabria, southern Italy. Journal of Hydrology, 248, 93-108.

Porto, P., Walling, D. E., Ferro, V., \& Di Stefano, C. (2003). Validating erosion rate estimates provided by caesium-137 measurements for two small forested catchments in Calabria, Southern Italy. Land Degradation and Development, 14, 389-408.

Walling, D. E. (1998). Use of ${ }^{137} \mathrm{Cs}$ and other fallout radionuclides in soil erosion investigations: progress, problems and prospects. In Use of ${ }^{137} \mathrm{Cs}$ in the Study of Soil Erosion and Sedimentation, IAEA-TECDOC-102839-62. Vienna, Austria: IAEA.

Walling, D. E., Collins, A. L., \& Sichingabula, H. M. (2003) Using unsupported lead-210 measurements to investigate soil erosion and sediment delivery in a small Zambian catchment. Geomorphology, 52, 193-213.

Walling, D. E., \& He, Q. (1999). Using fallout lead-210 measurements to estimate soil erosion on cultivated land. Soil Science Society of America Journal, 63(5), 1404-1412.

Zapata, F. (2003). The use of environmental radionuclides as tracers in soil erosion and sedimentation investigations: recent advances and future developments. Soil and Tillage Research, 69, 3-13. 